Scientific Bulletin, № 2, 2021, pages 7-13

Gunel Elmir Mammadova, gune12017m@gmail.com

Lankaran State University

DOI: doi.org/10.54414/cssy7041

e-ISSN: $2789-4614$

\title{
STRUCTURAL AND GRAMMAR CHARACTERISTICS OFPHRASEOLOGICAL UNITS EXPRESSING GENDER RELATIONSHIP IN AZERBAIJANI LANGUAGE
}

\begin{abstract}
The grammatical structure of phraseological combinations in Azerbai- jani language is one of the topics that were not investigated. Although many linguists have focused on this topic, this area has not been developed in Azerbaijani. In this study, the phraseological units were collected from both languages, their structure was studied and the most used ones were noted. The main tools that play the role of gender markers are anthropometric lexemes, and according to this the units containing noun predominate in the compounds. There are many units belonging to the verb compounds, and these compounds are divided into subgroups. At the end of the study, we observe that there are enough gender-marked combinations of the Azerbaijani language.
\end{abstract}

Keywords: gender, phraseology, word combination, linguistics.

\section{AZӘRBAYCAN DÍLINDӘ GENDER MÜNASIBӘTINI İFADӘEDӘN FRAZEOLOJI VAHIDLORIN STRUKTUR- QRAMMATIK XÜSUSIYYYTLӘRİ}

\section{XÜLASə}

Azərbaycan dilində frazeoloji birləşmələrin qrammatik strukturu tədqiq edilməmiş mövzulardandır. Başqa bir çox dilçilər bu mövzunu diqqət mərkəzinə çevirsələr də, Azərbaycan dilində bu sahə işlənilməmişdir. Bu araşdırmada, toplanmış frazeoloji vahidlərin tərkibi, onların quruluşu tədqiq edilmiş və ən çox istifadə olunanlar qeyd edilmişdir. Gender markerləri rolunu oynayan əsas vasitələr antropometrik leksemlər, qohumluq terminləridir. Bu vasitələr nitq hissəsi kimi isimlərə aiddir və bu səbəbdən birləşmələrin tərkibində ismin olduğu vahidlər üstünlük təşil edir. Feili birləşmələrə aid olan vahidlər də az deyildir və bu birləşmələr alt qruplara bölünmüşdür. Araşdırmanın sonunda Azərbaycan dilinin gender markerli birləşmələrinin kifayət qədər olduğunu müşahidə edirik.

Açar sözlər: gender, frazeologizm, söz birləşmələri, dilçilik

\section{СТРУКТУРНО-ГРАММАТИЧЕСКИЕ ХАРАКТЕРИСТИКИ ФРАЗЕОЛОГИЧЕСКИХ ЕДИНИЦ, ВЫРАЖАЮЩИХ ГЕНДЕРНЫЕ ОТНОШЕНИЯ НА АЗЕРБАЙДЖАНСКОМ ЯЗЫКЕ}

\section{PЕЗЮМЕ}

Грамматическая структура фразеологических сочетаний в азербайджанском языке - одна из тем, которые не исследовались. Хотя многие лингвисты сосредоточились на этой теме, в азербайджанском языке эта область не получила развития. В данном исследовании собраны фразеологизмы обоих языков, изучена их структура и отмечены наиболее упо- требляемые. Основными инструментами, играющими роль гендерных маркеров, являются антропометрические лексемы, и в соответствии с ними в составах преобладают единицы, содержащие существительное. К составным глаголам принадлежат многие единицы, и эти составы делятся на подгруппы. В конце исследования мы замечаем, что существует достаточно гендерномаркированных сочетаний азербайджанского языка.

Ключевые слова: гендер, фразеология, словосочетание, лингвистика. 
Azərbaycan dilində frazeologizmlərin struktur-qrammatik xüsusiyyətləri həm ümumi şəkildə, həm də konkret tipli (məsələn, somatik) frazeologizmlərə münasibətdə ayrı-ayrı müəlliflərin işlərində tədqiq olunmuşdur. Frazeoloji vahidin iki və daha artıq tammənalı sözün birləşməsi əsasında yaranmasını qeyd etmiş H.Bayramov onların müxtəlif tiplərinin olduğunu söyləmiş, quruluş və mənaca söz birləşməsi səciyyəsi daşıyan frazeoloji vahidləri frazeoloji birləşmə, quruluşca cümləni xatırladanları isə frazeoloji cümlələr adlandırmışdır. Bu mövqedən çıxış edən müəllif frazeoloji birləşmələri feili və qeyri-feili olmaqla iki qrupa bölmüşdür [3, səh. 70-71]. Tədqiqatçının bu fikri dilin tam frazeoloji sisteminə aiddir və gender frazeologiyasının da bu sistem daxilində yerləşməsini nəzərə alsaq, onda H.Bayramov mövqeyindən gender frazeologiyasını da frazeoloji birləşmə və frazeoloji birləşmələrə ayıra bilərik. Bununla belə, müasir dilçilikdə cümlə quruluşlu frazeologiyaya münasibətdə yeni elminəzəri baxışın formalaşması faktını bir kənara qoymaq da özünü doğrultmur.

İ.Həmidov cümlə tiplərinin fərdi semantik mücərrədləşdirmə pillələrini konsepsiyasını işləyərkən erkən uşaq nitqi vahidlər $\rightarrow$ klassik (kanonik) cümlə $\rightarrow$ universal anatomik konstruksiya $\rightarrow$ paremiya $\rightarrow$ predikativ quruluşlu frazeoloji vahidlər xəttini əsas götürməklə rus dili cümlələrinin məntiqi qrammatik universalı kimi şərh oluna biləcək nisbətən tam semantik modelini yaratmışdır [5, səh. 24].

Gender frazeologiyasının struktur-qrammatik səciyyəsini tədqiq edərkən bu modelə daxil olan vahidlərin təhlilə cəlb etməyəcəyik. İşdə gender frazeoloji birləşmələr araşdırılacaqdır. İngilis dilinin müvafiq birləşmələrinin tədqiqi prosesində olduğu kimi Azərbaycan dili materiallarını da ikikomponentli, üçkomponentli və çoxkomponentli birləşmələr üzrə təhlil etmək məqsədəuyğundur. Belə yanaşma iki dilin materialları əsasında müqayisəli araşdırmalar üçün zəmin yaradacaqdır.

M.Mirzəyeva göstərir ki, birləşmə səviyyəli frazeoloji vahidlər kateqorial mənasına görə ismi və feili birləşmələrə ayrılır [4, səh. 85].

Dilçilikdə, o cümlədən də Azərbaycan dilçiliyində bu fikir yeni olmasa da, frazeoloji birləşmələrin struktur-qrammatik cəhətdən təsnif etməkdə apar1cıdır. Belə yanaşmanın mahiyyətinə vardıqda morfoloji səviyyədə belə ayırmanın yeganə olması qənaətinə gəlmək də mümkündür. Frazeoloji birləşmələrin tərkib komponentləri, təbii ki, adlar və feillərə bölünməklə iki qrupu təyin etməyə əsas verir. Birləşmə ikikomponentli olduqda ayırma sadələşir. Lakin komponentlər sayı artdıqda müəyyən çətinliklər meydana çıxır. Bu halda məsələ kateqorial mənanı təyin etməklə semantik-qrammatik qruplaşdırma aparmaq olur. Başqa bir mil frazeoloji birləşmənin nüvə sözünün müəyyənləşdirilməsi ilə əlaqələnir. Đslində kateqorial məna da, frazeologizmlər üçün vacib şərt olan məcazlaşmada nüvə sözün üzərində cəmləşir. Bu, struktur-qrammatik xüsusiyyətlərin öyrənilməsində əhəmiyyətli məsələdir. Lakin əgər frazeoloji birləşmələri başqa bir əlamət üzrə də qruplaşdırmaq tələb olunarsa və bu 
zaman seçim meyarı birləşmənin tərkibindəki leksemlərdən biri və ya hamısı ilə bağlanırsa, onda təsnifat ikili proses səciyyəsi daşıyır. Məsələn, somatik frazeoloji birləşmələri ayırmaq üçün frazeologizmlərin tərkibindəki somaqizmlər diqqət mərkəzinə çəkilir. Təbii ki, gender frazeologizmlərinin də müəyyənləşdirilməsində aparıcı rolu genderizmlər, yaxud gender makerli leksemlər oynayacaqdır.

Gender markerləri rolunu oynayan əsas vasitələr antropometrik leksemlər, qohumluq terminləridir. Bu vasitələr nitq hissəsi kimi isimlərə aiddir. Onların iştirakı ilə düzələn gender frazeoloji birləşmələrinin bir və ya daha çox komponenti də isimlər alacaqdır. Feillərdə genderoloji əlamət çox az hallarda özünü göstərir. Belə olan halda ikikomponentli gender frazeoloji birləşmələrinin bir komponentinin gender markeri funksiyasını yerinə yetirən isim olmas1 qabaqcadan bəllidir. İngilis dilində gender münasibətini ifadə edən frazeoloji vahidlərin struktur-qrammatik xüsusiyyətlərinin tədqiqi göstərir ki, bu dildə ismi gender frazeoloji birləşmələr çoxluq təşkil edir. Azərbaycan dilində gender frazeoloji birləşmələrdə mümkün paylanmanın təyini konkret təhlil tələb edir. Bu məqsədlə əvvəlcə Azərbaycan dilində qeydə aldığımız ikikomponentli gender frazeologizmlərini struktur-qrammatik təhlilə cəlb edək. Onu da qeyd edək ki, Azərbaycan dilinin gender frazeologizmlər korpusu ingilis dili ilə müqayisədə kifayət qədər böyük görünmür.

İsim+isim modeli $(\mathbf{N}+\mathbf{N})$. Azərbaycan dilində bu modeldən olan tərkibində gender markerli leksemlər işlənən frazeoloji birləşmələr müəyyən çoxluq yaradır. Məsələn, baba ocağı, ata ocağı, ana xətt, ana uşağı, Adəm alması, arvad bazarı, arvad söhbəti, ay parçası, centlemen razılaşması, cik-cik xanım, Damokl q1lıncı, dil pəhləvanı, düşmən çəpəri, erkək Tükəzban, Ezon dili, İmran dili, kişi qırı̆̆ı, Sizif əməyi, bı̆̆ yağı və s.

Nümunələr arasında I növ təyini söz birləşməsi formasındadır: ana xətt, cik-cik xanım, erkək Tükəzban. Yanaşma əlaqəsi ilə formalaşan bu frazeoloji birləşmələrdə gender əlaməti ana, xanım, erkək, Tükəzban leksik vahidlərinin hesabına təyin olunur.

Ana xətt - əsas, həlledici, leytmotiv [2, səh. 23]. "Ana" qohumluq terminidir, ailədə qadın cinsini təmsil edir. Ana ailənin dayaq sütunu, qurucusu və inkişaf etdirənidir. Övladların dünyaya gəlməsi, böyüməsi və beləliklə ailənin genişlənib möhkəmlənməsi anadan çox asılıdır. Bilavasitə ailə həyatı ilə bağlı olan çox sayda işləri ana həyata keçirir. O, yemək hazırlayır, evdə səliqə-səhman yaradır, paltar yuyur, uşaqların qayğısına qalır, onların tərbiyəsi ilə məşğul olur və s. Bütün bunlar ananın ailədə əsas sayılmasını, vacibliyini göstərir. Frazeoloji birləşmənin "əsas", "həlledici" mənaları da ana sözü ilə motivlənir, onun məcazi mənasına söykənir. Frazeoloji birləşmə tərkib komponentinə görə, gender markerlidir. Onun ifadə etdiyi mənada isə gender əlaməti iştirak etmir. Yəni birləşmə dildə işləndikdə genderi, genderə görə seçilən predmeti, gender əlamətini ifadə etmir. Bir işin, fəaliyyətin, hərəkətin mü- 
hüm, vacib, aparıcı, əsas hissəsini bildirir.

"Cik-cik xanım" frazeoloji birləşməsi lüğətdə "bəzi çoxbilmiş, bacarıqlı, çalışqan qadınlar haqqında işlədilən ifadə" kimi izah edilmişdir [2, səh. 72]. Frazeoloji birləşmədə gender markerli leksem "xanım” sözüdür. Qadın cinsini bildirir, sosial statuslu adamların arvadlarına aid edilmişdir. Tədricən ailədə qadınlara deyilən söz kimi geniş istifadə dairəsi almışdır. Ovvəllər yalnız qadınlara aid olunsa da, sonralar qızlara da şamil edilmişdir. Hazırda qadın cinsindən olanlara hörmət mənasında müraciyət forması kimi çox işlənir.

"Cik-cik xanım" birləşməsindəki xanım genderoloji əlaməti dəqiq təyin edir və ifadədə gender aidliyi həmişə mövcuddur. Lüğətdəki izahın işgüzarlıq, çalışqanlıq ilə əlaqəsi səbəbini, şübhəsiz ki, "cik-cik" təqlidi sözündə axtarmaq lazımdır. Yumurtadan yeni çıxmış cücələrin daha çox çıxartdığı, ola bilsin yem, qayğ 1 istəyini ifadə edən səsdir. Onun, yəni "cik-cik" sözünün çalışqanlılıq, çoxbilmişliklə motivləşmə səbəbini aydınlaşdırmaq çətindir. Onu da qeyd edək ki, Azərbaycan dilində "tıq-tıq" xanım frazeoloji birləşməsi də işlədilir. Bu birləşmə uşaq nağılı qəhrəmanlarının adından götürülmüşdür. Zahirən çox da gözəl olmayan, lakin özünü həmin dərəcədə təqdim edən, həmçinin çox səs-küy salan qadın və qızlar haqqında işlədilir.

"Adətən ayaqlarını sürüyərək gəzən və bu zaman taqq1ltı salan arıq və yeniyetmə qızları səciyyələndirmək üçün işlədilir" [1, səh. 334].

"Zeynəb, Seyfulla əminin anadan yetim qalmış təkcə q1zı, çit paltarda, qolları açıq, əlində "trofey" sumka, Tıq-Tıq xanım kimi, şappaşap-şappaşap pilləkənləri enərək, heç kəsə məhəl qoymadan, ayaq saxlamadan həyətin darvazasına sarı yönələcək: guya heç kəsi tanımır (Səmədoğlu, "Qətl günü", s.)

"Dozanqurdu edirdi

yalquzlıqdan şikayət,

Soğan qabiqlarından

Bir qarda tikdi şıq-şıq.

Findiq qabıqlarından

Çarıq geyindi, tıq-tıq" (Abdulla Şaiq).

Ayaqqabılarının dabanı döşəməyə dəyəndə möhkəm səs çıxaran, yaxud bilə-bilə ayaqlarını yerə bərk vurmaqla özünü göstərən qızlar, qadınlar haqqinda da bu addan istifadə olunur.

Birləşmədə "tıq-tıq" təqlidi söz kimi qəbul edilir. Məcazlaşma bənzətmə yolu ilə keçmişdir. Yalnız səs oxşarlığı deyil, xarakter, xasiyyət oxşarlığı nəzərdə tutulmaqla istifadə olunur.

"Erkək Tükəzban - kişi təbiətli, özünü kişi kimi aparan, kişi ədalı, incə davranmayan qadın haqqında işlədilən ifadə" [2, səh. 102]. Birləşmənin tərkibində cins semantikasına malik iki isim $(\mathrm{N}+\mathrm{N})$ vardır. "Erkək" kişi cinsi informasiyasını verir. Tükəzban qadın adını ifadə edən antroponimdir. Deməli, erkək Tükəzban birləşməsinin hər iki komponentində gender semantikası vardır və bu, antonimliyi ilə də diqqət cəlb edir. "Erkək" sözü Tükəzbanı cinsə 
görə təyin edir. Frazeologizmin ümumi mənasının formalaşmasında bu əlamət əhəmiyyətli rol oynamışdır.

Antroponimlər kişi və qadın adları ifadə etmək baxımından fərqlənir. Azərbaycan qadın adları sistemində Fatma və Tükəzban antroponimlərinin də öz yeri vardır. Bu adlar sadə Azərbaycan qadını adları sayılmış, "Fatma - Tükəzban" birləşməsi geridə qalmış, avam, hüquqsuz, bədbəxt Şərq qadınlarını səciyyələndirərkən ümumiləşmiş şəkildə ədəbi dildə işlədilir [1, səh. 348].

Maraqlıdır ki, Fatma adı "Kitabi-Dədəm Qorqud" dastanlarında işlənir və personaj müsbət obraz kimi təqdim edilmir.

"Eviniz (ard1) dərəcik degilmiydi?

(İtüniz) adı Bıraq degilmiydi?

Sənin adın Qırq oynaşlu Boğazca Fatma degilmiydi?

Dəxi eybin açaram, bəlli, bilgil! - dedi” (KDQ)

Fatma və Tükəzban Şərq qadınlarının ümumiləşdirilmiş adı kimi bədii nümunələrdə istifadə olunur.

"Xoşlamırıq bir para nadanları

Şiveyi-pisvani-müsəlmanları.

Neyləyirik Fatma, Tükəzbanları"

"Ana Vətən" N+N modeli üzrə əmələ gəlmiş birləşmədir. Gender markeri "ana" leksemidir. Gender marker "ana" leksemidir. Oslində ana və Vətənin eyniləşdirilməsi də geniş yayılmışdır. Ana müqəddəs olduğu üçün Ana Vətən də müqəddəs, toxunulmaz və ən sevilən sayılır. "Qədim türk panteonunda Od Ana /Ot Ana/Atəş Ana (od tanrısi), Gün Ana (günni), Su ana buradan da - ("Ana Kür") və s. tanrılar müqəddəs sayılırdı" [1, səh. 30].

$\mathrm{N}+\mathrm{N}$ modelli sabitləşmiş başqa birləşmələr də vardır ki, onların tərkibindəki sözlərdə gender semantikası aşkara çıxır Qaçaq Nəni, Qoç Koroğlu, Yel Baba, Mirzə Səfər, Molla Nəsrəddin və s. Gender markerli bu sabitləşmiş birləşmələrin gender frazeoloji birləşmələrə aid edilməsinə mübahisəli cəhətlər vardır. Həmin mübahisəli məqamlar bilavasitə gender əlaməti ilə bağlı olmayıb bu cür birləşmələrin ümumiyyətlə frazeologizm kimi təyini məsələsini əhatə edir.

$\mathrm{N}+\mathrm{N}$ modelli gender frazeologizmlərinin ikinci növ təyini birləşməsi şəklində formalaşması daha geniş yayılmışdır. Ata ocağı, baba ocağı, arvad bazarı, arvad söhbəti, Koroğlu arşını, ana uşağı, dil pəhləvanı, düşmən çəpəri və $\mathrm{s}$.

Baba ocağ - ata, baba yurdu, əcdadları yaşamış olduğu məkan [2, səh. 33]. Bu frazeoloji vahid ata ocağı şəklində də işlənir. Ailə münasibətlərində atanın ailə başcısı, rəhbər mövqeyi yurdun, evin onun ocağı adlandırmasını reallaşdırmışdır. Azərbaycan ailəsində ata xətti aparıcı və əsas sayılmışdır. Nəzərə almaq lazımdır ki, yurd yeri, məkan, ev, ataya da onun atasından qalır. Bu baxımdan məsələyə nəsil müstəvisindən yanaşdıqda "baba ocağı" frazeologizminin işlənmə səbəbi aydınlaşır. Evdə atadan başqa baba da yaşadıqda 
rəhbərlik, idarəetmə, ağsaqqallıq babada olur və "baba ocağı" variantı actuallaşmır.

Frazeoloji birləşmələrdə variantlılıq mümkün haldır və bu özünü gender frazeologizmində də göstərir. Baba ocağı / ata ocağı frazeoloj birləşmələrində cins əlaməti kişini ifadə edir. Motivləşmə kişinin evdəki üstün, hakim mövqeyi ilə izahını tapar.

Arvad bazarı - səs-küylü, danışanın çox, dinləyənin az olduğu yer haqqinda [2, səh.27]. Cins markerli "arvad" antropometrik leksemində ifadəsini tapmışdır. Bu birləşmədə "arvad" sözü qohumluq termini kimi çıxış etmir, qadın cinsini bildirir və yaşca böyüklüyü nəzərdə tutur. Qadınlar danışmağa meyilli olduqlarından oların çox toplaşdığ 1 yerdə səs-küy də çox olur. Eyni zamanda bir vaxtda danışmaq, bir-birini dinləməmək də bu cinsin təmsilçiləri üçün xarakterikdir. Frazeoloji birləşmənin ümumi mənasının formalaşmasında bu xüsusiyyət öz rolunu oynamışdır. İkinci komponent olan "bazar" sözündə adamların çox toplandığ (məsələn, qiymətdə) razılığa gəldiyi yer semantikası özünə yer alır. Məhz bu baxımdan frazeoloji birləşmənin ümumi mənası səs-küylü yer anlamı formalaşır.

Frazeoloji birləşmə $\mathrm{N}+\mathrm{N}$ modeli üzrə qurulmuşdur. İkinci komponent mənsubiyyət şəkilçisi qəbul etmişdir. Birinci komponent qadınlara xas olan ünsiyyəti aktuallaşdırır. Qadınlar daha çox məişət mövzularında söhbət edir, qeybət qırırlar. Bu baxımdan "arvad söhbəti” qeyri-ciddi danışıq, məişət söhbəti, qeybət mənasinı verir.

$\mathrm{N}+\mathrm{N}$ modeli üzrə düzəlmiş gender frazeologizmləri arasında üçüncü növ təyini söz birləşməsi formasında olanları da vardır. Məsələn, Nuhun gəmisi, Nuhun tufan1, İsgəndərin buynuzu.

Azərbaycan dilinin gender frazeologiyasında feili birləşmələr çoxluq təşkil edir. Feili birləşmələr üçün əsas səciyyəvi model ikidir: N+V və $\mathrm{N}+\mathrm{N}+\mathrm{V}$. Məsələn, azad olmaq, ana-bala etmək, anadan olmaq, anasını ağlatmaq, atasını yandırmaq, anasının qarnında öyrənmək, anasının əmcəyini kəsmək, boğaz qalmaq, boğaz olmaq, boynuna uşaq düşmək, başa örpək bağlamaq, başa ləçək bağlamaq, başına ləçək örtmək, bəxti açılmaq, bəxti bağlanmaq, bığ yeri tərləmək, saç ağartmaq, birçək ağartmaq və s.

\section{Odəbiyyat:}

1. Adilov M.I., Verdiyeva Z.N., Ağayeva F.M. İzahlı dilçilik terminləri. Bakı, Marif, 1989, s. 364

2. Azərbaycan dilinin frazeologiya lüğəti, s. 23

3. Bayramov H. Azərbaycan dili frazeologiyasının əsasları. Bakı, Maarif, 1978

4. Mirzəliyeva M. Türk dillərinin frazeologiyası. I c. Bak1, Nurlan, 2009, 
s. 220

5. Гамидов И. Философия грамматики паремио-фразеологических единиц, 2017, с. 24 